\title{
Pyroligneous Liquor Produced at Different Heating Rates in Pyrolysis of Eucalyptus Wood
}

\author{
Raquel Silveira Ramos Almeida*, Marcel Miranda Taccini, Luiz Fernando de Moura, Udemison Luis Ceribelli and \\ José Otávio Brito
}

Department of Forest Science, Univerity of São Paulo, Brazil

*Corresponding author: Raquel Silveira Ramos Almeida, Henraq Consultoria e Treinamento Ltda, Al. Bauru, SP, Brazil

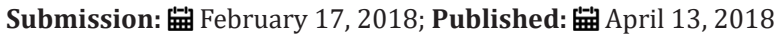

\begin{abstract}
The objective of this research was to analyze the influence of two different heating rates $\left(2.67{ }^{\circ} \mathrm{C} / \mathrm{min}, 0.67{ }^{\circ} \mathrm{C} / \mathrm{min}\right)$, reaching $500{ }^{\circ} \mathrm{C}$ as final temperature in pyrolysis, on the chemical composition of the pyroligneous liquor produced. Three pyrolysis sessions were performed for each heating rate on Eucalyptus urograndis wood chips in an oven-muffle connected to a gas-collecting system. The gravimetric yield was calculated, and the chemical compounds of pyroligneous liquors were identified through gas chromatograph-mass spectrometer. Heating rates did not affect the gravimetric yield of final products. However, qualitative differences were observed in the chemical composition of pyroligneous liquors produced. The presence of 1-hidroxy 2-propanone, 4-methylphenol ( $\mathrm{p}$-cresol), and 5-hidroxymethyl 2-furaldehyde compounds was detected only in the pyroligneous liquor produced at the highest heating rate $\left(2.67^{\circ} \mathrm{C} / \mathrm{min}\right)$.

Category: Forestry Science
\end{abstract}

Keywords: Carbonization; Pyrolysis gases; Gravimetric yield; Eucalyptus; Chromatograph; Mass spectrometry

\section{Introduction}

Charcoal production is based on the pyrolysis process of wood or other vegetable biomass, which in the current industrial practice is called carbonization. In theory, this process can be considered as the heating of a solid material in an inert atmosphere with an average temperature of $500{ }^{\circ} \mathrm{C}$ [1]. Besides the charcoal, the carbonization process produces volatile materials that can be divided into two distinct fractions: one condensable and the other non-condensable. The yield of products is a function of the characteristics of the biomass to be treated, as well as the pyrolysis method applied and the process parameters, such as:

I. Temperature,

II. Residence time,

III. Heating rates and

IV. Pressure [1,2].

According to [3], nearly $60 \%$ of the weight of a wood charge submitted to carbonization is transformed into volatile products, which are released into the atmosphere. Despite the fact that the most of the charcoal production is carried out in smallscale factories spread over the countryside, the overall amount of emissions is important, both with respect to environmental impact and to the level of valuable chemical products that could be economically recovered [3].

Among the chemical compounds released during the carbonization process, the following stand out in their potential for recovery and industrial use: in the condensable fraction

a. Acetic acid, methanol, acetone, aromatic compounds, phenol derivatives, aldehydes and derivatives; and in the noncondensable fraction.

b. $\mathrm{CH}_{4}, \mathrm{CO}_{2}, \mathrm{CO}, \mathrm{H}_{2}$ and other light hydrocarbons $[1,3]$.

The exploitation of any potentially useful substances in the gaseous by-products of carbonization depends on the adoption of more efficient operational practices and the use of improved technologies. Thus, research and development activities to improve the control of the carbonization parameters are necessary, to lead the charcoal sector to a more efficient technical-economical management.

Therefore, these carbonization experiments were carried out to analyze the influence of different heating rates of the carbonization process on the yield of solid (charcoal) and yield and chemical composition of condensable fraction from the volatilized gases. 


\section{Materials and Methods}

\section{Material used}

Eucalyptus urograndis wood chips were used in the experiment. This is an inter-specific hybrid clone that combines the rapid growth characteristics of Eucalyptus grandis (a species widely distributed for charcoal production in the states of Minas Gerais and São Paulo) with the higher density and phenotypic variety of E. urophylla (a species that is strategically important for genetic improvements in fields related to clonal forestry) $[4,5]$

\section{Wood pyrolysis and collection of by-products}

All the laboratory experiments were conducted in the laboratories of Chemistry, Pulp and Energy in Piracicaba, São Paulo, Brazil. The carbonizations were processed at a final temperature of $500{ }^{\circ} \mathrm{C}$, under atmospheric pressure, at 2 different heating rates and residence times (Table 1 ). Three repetitions were performed for each heating rate, for a total of 6 carbonizations. All carbonizations started at an initial temperature of $100{ }^{\circ} \mathrm{C}$, which was held for 30 minutes before increasing, and reached a final temperature of $500{ }^{\circ} \mathrm{C}$, which was also held for 30 minutes. According to $[6,7]$, this condition is enough to allow the gases to attain their maximum emission peak and their subsequent stabilization. The carbonizations were performed in an oven-muffle heated by an electrical resistance, with an analog meter for temperature control. A metallic recipient (nominal volume of $500 \mathrm{~cm}^{3}$ ) was inserted inside the muffle, containing samples of wood. The amount of wood used in each carbonization was fixed according to the maximum occupation capacity of the metallic recipient volume. The ovenmuffle was equipped with a system that allowed the collection and separation of condensable and non-condensable gases (Figure 1), which were submitted to chemical analysis.

Table 1: Heating rates and total time of carbonizations.

\begin{tabular}{|c|c|c|}
\hline $\begin{array}{c}\text { Experimental } \\
\text { Groups }\end{array}$ & Heating Rates & $\begin{array}{c}\text { Total Time of } \\
\text { Carbonizations }\end{array}$ \\
\hline 1 & $2.67^{\circ} \mathrm{C} / \mathrm{min}$ & 2.5 hours \\
\hline 2 & $0.67^{\circ} \mathrm{C} / \mathrm{min}$ & 10 hours \\
\hline
\end{tabular}

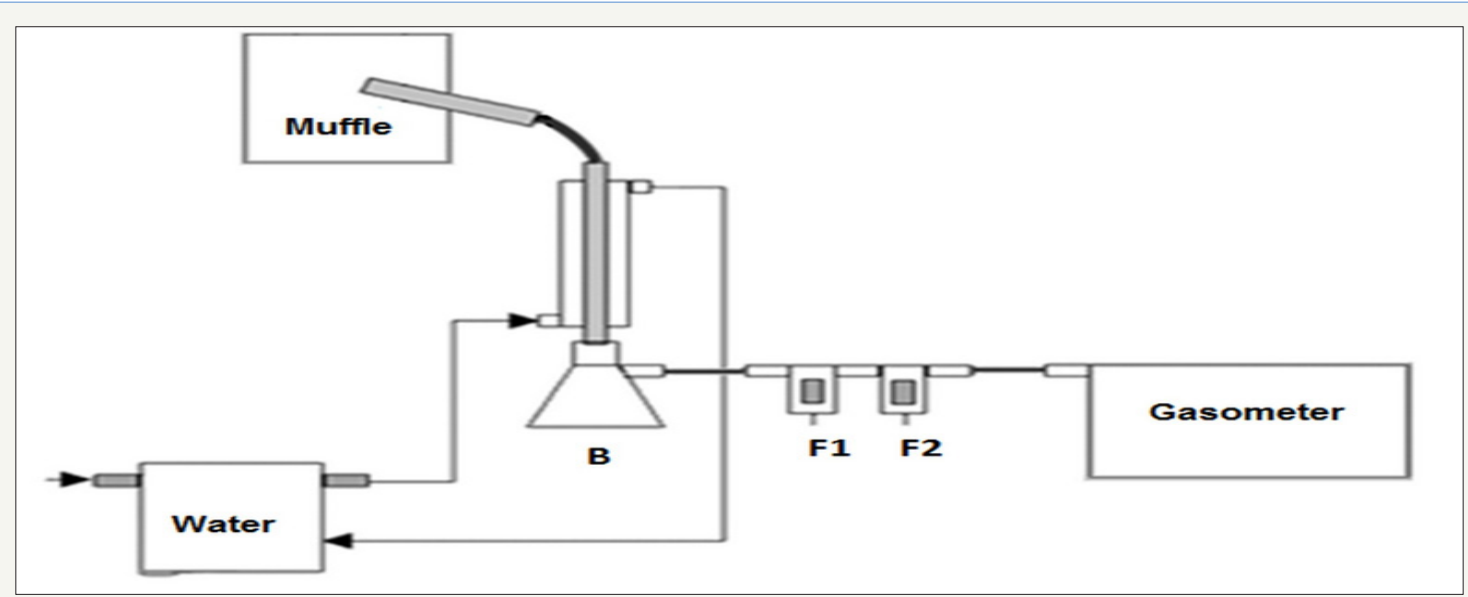

Figure1: Oven-muffle connected with the gas collector system.

B: condensable-gases collector;

F1 and F2: A non-condensable gas filters.

B: Balão de coleta dos gases condensáveis

F1 e F2: Filtros de purificação dos gases não condensáveis

\section{Gravimetric yield calculations}

After cooling the oven-muffle, the charcoal and condensablegases (pyroligneous liquor) produced were weighed in a semianalytic balance to measure the gravimetric yield for the charcoal and gaseous by-products. The charcoal gravimetric yield was obtained from the ratio between the weight of dry charcoal and wood (Equation 1), and that for the condensable-gases from the ratio of pyroligneous liquor and wood (Equation 2). The results for the charcoal and condensable gases gravimetric yields were submitted to variance analysis, to verify if the heating rates and carbonization times applied influenced these parameters.

$$
\mathrm{CGY}=\mathrm{DCW} / \mathrm{DWW} \times 100 \quad \text { Eq.(1) }
$$

Where CGY = Dry charcoal gravimetric yield (\%); DCW = Dry charcoal weight (grams); DWW = Dry wood weight (grams)

$\mathrm{PLY}=\mathrm{CGW} / \mathrm{DWW} \times 100$

Where PLY = Pyroligneous liquor gravimetric yield (\%); CGW $=$ Condensable-gases weight (grams); DWW = Dry wood weight (grams)

\section{Qualitative Analysis of Pyroligneous Liquor}

For the identification of chemical compounds present in the pyroligneous liquor produced at the heating rates applied, the condensable-gases were analyzed in a gas chromatograph connected to a mass spectrometer (GC/MS) using a TRACE GC 
Ultra, Thermo brand equipped with DSQII. A silica capillary column $(30 \mathrm{~m} \times 0.30 \mathrm{~mm}$ ID $\times 0.25 \mu \mathrm{m})$ was used. The temperature was programmed initially for $40{ }^{\circ} \mathrm{C}(3 \mathrm{~min})$ and then increased at a rate of $15{ }^{\circ} \mathrm{C} / \mathrm{min}$ to $270{ }^{\circ} \mathrm{C}(6 \mathrm{~min})$. Helium was used as carrier gas. The volume injection was in split mode at $250^{\circ} \mathrm{C}$. The interface temperature was $270{ }^{\circ} \mathrm{C}$. The split flow was $24 \mathrm{ml} / \mathrm{min}$ and the split ratio was 20. The data was processed using Excalibur software. The results were compared to identify qualitative differences in the pyroligneous liquors produced in each experimental group.

\section{Results and Discussion}

\section{Gravimetric yield results}

The gravimetric yield results are shown in (Table 2). Results of charcoal and pyroligneous liquor gravimetric yields showed normal distribution, as provided by the Shapiro-Wilk test $(\alpha=0.05)$, and could be submitted to analysis of variance (ANOVA). The ANOVA indicated no statistical differences for the gravimetric yields of pyroligneous liquor $(p=0.6801)$ and charcoal $(p=0.0971)$ at the different heating rates applied. Thus, despite the finding of [6-9] in which the heating rates influenced the gravimetric yield of the pyroligneous liquor, no such effect was observed in this experiment. However, [10] reported results similar to those obtained in this experiment. It can be justified that the range of heating rates applied for these studies are smaller than those mentioned by other researchers.

Table 2: Gravimetric yields obtained.

\begin{tabular}{|c|c|c|}
\hline Carbonizations & CGY (\%) & PLY (\%) \\
\hline \multicolumn{3}{|c|}{ Group $1\left(2.67^{\circ} \mathrm{C} / \mathrm{min}\right)$} \\
\hline $1 \mathrm{a}$ & 36.3 & 42.2 \\
\hline $1 \mathrm{~b}$ & 38.8 & 42.6 \\
\hline
\end{tabular}

\begin{tabular}{|c|c|c|}
\hline 1c & 38.5 & 41.1 \\
\hline Average & 37.8 & 41.9 \\
\hline $\begin{array}{c}\text { Standard Deviation } \\
\text { Coefficient of } \\
\text { Variation }\end{array}$ & 1.3 & 0.8 \\
\hline \multicolumn{2}{|c|}{ Group 2 $\left(0.67^{\circ} \mathrm{C} / \mathrm{min}\right)$} \\
\hline 2a & 38.9 & 1.8 \\
\hline 2b & 38.7 & 36.3 \\
\hline 2c & 38.5 & 40.0 \\
\hline Average & 38.7 & 40.1 \\
\hline $\begin{array}{c}\text { Standard Deviation } \\
\text { Coefficient of } \\
\text { Variation }\end{array}$ & 0.2 & 38.8 \\
\hline
\end{tabular}

Where CGY = Dry charcoal gravimetric yield (\%), PLY = Pyroligneous liquor gravimetric yield.

\section{Pyroligneous liquor analysis results}

The results of chemical analyses can be seen in (Table 3) that summarizes the chemical compounds present in the chromatograms of (Figures $2 \& 3$ ) which in turn describe only the 19 compounds that had the most representative percentile concentration for each experimental group tested. The chemical analysis of pyroligneous liquors demonstrated the presence of oxygenated compounds, such as carboxylic acids, esters, ethers and ketones, in addition to phenol, phenol derivatives and guaiacol. Its revealed that the most of the pyroligneous liquor compounds identified had complex structures derived from the chemical degradation of the lignocellulosic constituents of eucalyptus wood, as described by [10-12].

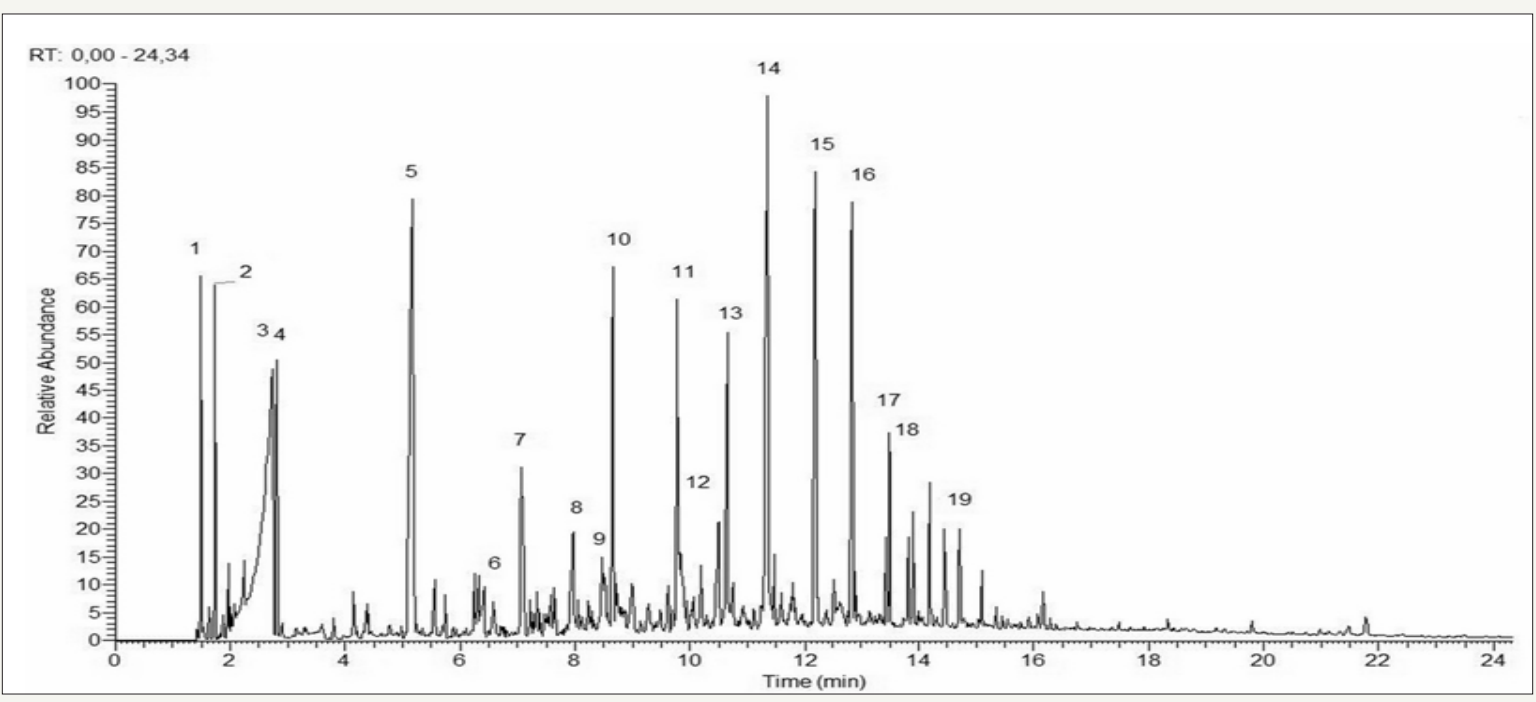

Figure 2: Chromatogram of pyroligneous liquor obtained from experimental group $1\left(2.67^{\circ} \mathrm{C} / \mathrm{min}\right)$.

The numbers on the peaks correspond to the chemical components listed in (Table 3). 


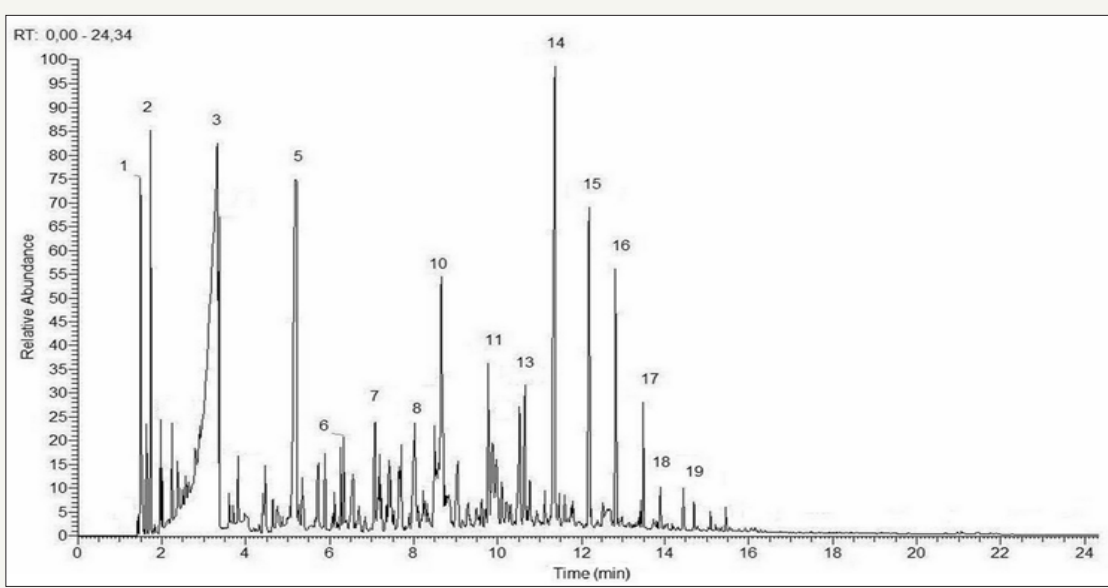

Figure 3: Chromatogram of pyroligneous liquor obtained from experimental group $2\left(0.67{ }^{\circ} \mathrm{C} / \mathrm{min}\right)$.

The numbers on the peaks correspond to the chemical components listed in (Table 3).

Table 3: Chemical compounds present at pyroligneous liquor.

\begin{tabular}{|c|c|c|}
\hline Chemical Compounds & $\begin{array}{c}\text { Group } 1 \\
\left(2.67^{\circ} \mathrm{C} / \mathrm{min}\right)\end{array}$ & $\begin{array}{c}\text { Group } 2 \\
\left(0.67^{\circ} \mathrm{C} / \mathrm{min}\right)\end{array}$ \\
\hline Methanol & 1 & 1 \\
\hline Methyl acetate & 2 & 2 \\
\hline Acetic acid & 3 & 3 \\
\hline 1-Hydroxy, 2-propanone & 4 & nd \\
\hline 3-Furaldeyde & 5 & 5 \\
\hline 1-2-Furanil ethanone & 6 & 6 \\
\hline 5-Methyl, 2-furaldeyde & 7 & 7 \\
\hline Corilon & 8 & 8 \\
\hline 4-Methylphenol & 9 & nd \\
\hline 4-Methoxyphenol & 10 & 10 \\
\hline 2-Methoxy,4-methylphenol & 11 & 11 \\
\hline 5-Hydroxymethyl, 2-furaldeyde & 12 & nd \\
\hline 4-Ethyl,2-methoxyphenol & 13 & 13 \\
\hline 2,6-Dimethoxyphenol & 14 & 14 \\
\hline 1,2,4-Trimethoxybenzene & 15 & 15 \\
\hline 5-tert-Butylpyrogallol & 16 & 16 \\
\hline 4-Propyl-1,1-diphenyl & 17 & 17 \\
\hline $\begin{array}{c}\text { 4-Hydroxy,3,5- } \\
\text { dimethoxybenzaldeyde }\end{array}$ & 18 & 18 \\
\hline Desaspidinol & 19 & 19 \\
\hline
\end{tabular}

Where nd $=$ not detected.

More than 70 chemical compounds identified in the chromatograms were the same for both experimental groups. However, 3 compounds (1-hydroxy 2 propanone, 4-methylphenol and 5-hydroxymethyl 2-furaldehyde) appeared in the pyroligneous liquor produced by experimental group $1\left(2.67{ }^{\circ} \mathrm{C} / \mathrm{min}\right)$, but not by group $2\left(0.67^{\circ} \mathrm{C} / \mathrm{min}\right)$. The differences in chemical composition of pyroligneous liquors, obtained in this study as a function of different heating rates, can be explained by the fact that the highest heating rate induced higher temperatures and pressures in a relatively shorter time. Thus, increasing heating rates induce higher energy inputs into wood chemical components during pyrolisis in a shorter time, which induces faster thermal degradation by breaking chemical bonds.

This can explain the production of a higher variety of condensable gas figures at the highest heating rate. Moreover, the highest heating rates might have increased the exhaustion speed of gases from the reactor, thus minimizing exothermic reactions of secondary pyrolysis [13]. This latter aspect might have reduced thermal destruction of high-molecular weight gases inside the ovenmuffle chamber, and further conserved the original composition of condensable gases during sampling, which resulted in a higher variety of detectable compounds in chemical analysis.

\section{Conclusion}

The pyroligneous liquor was composed by a great number of oxygenated compounds including carboxylic acids, esters, ethers and ketones, in addition to phenol, phenol derivatives and guaiacol. Additionally, it can be concluded that the different heating rates applied for this study to reach the $500{ }^{\circ} \mathrm{C}$ final temperature $(2.67$ ${ }^{\circ} \mathrm{C} / \mathrm{min}$ and $0.67{ }^{\circ} \mathrm{C} / \mathrm{min}$ ) have not influenced the gravimetric yield of the charcoal and the pyroligneous liquor. Nevertheless, the qualitative chemical composition of the pyroligneous liquor was influenced, since the compounds 1-hidroxy 2-propanone, 4-methylphenol (p-cresol) and 5-hidroxymethyl 2-furaldehyde were found only in the pyroligneous liquor produced under the highest heating rate [14].

\section{References}

1. Gomez EO (2008) Fast pyrolysis of lignocellulosic for the production of biooil. In: Cortez LAB, Lora EES, Gómez EO (Eds.), Biomass for energy. Campinas, SP: Editora da Unicamp, Brazil, pp: 353-418.

2. Luengo CA (2008) Pyrolysis and torrefaction of biomass. In: Cortez LAB Lora EES, Gómez EO (Eds.), Biomass for energy. Campinas, SP: Editora da Unicamp, Brazil pp: 333-352.

3. Brito JO (1990) Principles of production and use of wood charcoal Forestry Documents. Piracicaba, Brasil, 9: 1-19. 
4. Assis JB (2001) de. Política florestal em Minas Gerais. In: Mello MG (Edt.), Biomassa, energia dos trópicos em Minas Gerais. Belo Horizonte: Lab Mídia, Fafich, Brazil, p: 115-132.

5. Couto L, Müller MD (2008) Energy Forestry in Brazil. In: Lora EES, Gómez EO (Eds.), Biomass for energy. Campinas: Editora da Unicamp, Cortez LAB, Brazil p: 93-110.

6. González JF, Encinar JM, Canito JL, Sabio E, Chacón M (2003) Pyrolysis of cherry stones: energy uses of the different fractions and kinetic study. Journal of Analytical and Applied Pyrolysis 67(1): 165-190.

7. Becidan M, Skreiberg 0, Hustad J (2007) Products distribution and gas release in pyrolysis of thermally thick biomass residues samples. Journal of Analytical and Applied Pyrolysis 78(1): 207-213.

8. Encinar JM, Beltran FJ, Bernalte A, Ramiro A, Gonzalez JF (1996) Pyrolysis of two agricultural residues: olive and grape bagasse. Influence of particle size and temperature. Biomass and Bioenergy 11(5): 397 409.

9. Taccini MM (2010) Estudo das metodologias da Convenção-Quadro das Nações Unidas sobre Mudanças Climáticas, referentes a avaliação de emissões de gases do efeito estufa na produção de carvão vegetal. 71f. Dissertação (Mestrado em Ciências Florestais)-Universidade de São Paulo-Escola Superior de Agricultura Luiz de Queiroz, Piracicaba, Brazil.

10. Martins AF, Diniz J, Stahl JA, Cardoso AL (2007) Caracterização dos produtos líquidos e do carvão de pirólise de serragem de eucalipto. Química Nova São Paulo 30(4): 873-878.

11. Esteves B, Graça J, Pereira H (2008) Extractive composition and summative chemical analysis of thermally treated eucalypt Wood. Holz for schung, 62(3): 344-351.

12. Ratanapisit J, Apiraksakul S, Rerngnarng A, chungsiriporn J, Bunyakarn C (2009) Preliminary evaluation od production and characterization of wood vinegar from rubber wood. 2009 Songklanakarin J Sci Technol Tailândia 31(3): 343-349.

13. Encinar JM, González JF, González J (2000) Fixed-bed pyrolysis of Cynara cardunculus L. product yields and compositions. Fuel Process. Technol 68(2): 209-222.

14. Brito JO (2005) Vegetable coal: the degradation of environmental strategies. Wood charcoal: from the degradation to environmental strategies. Visão Agrícola, 4: 26-27.

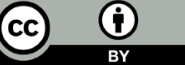

Creative Commons Attribution 4.0 International License

For possible submissions Click Here

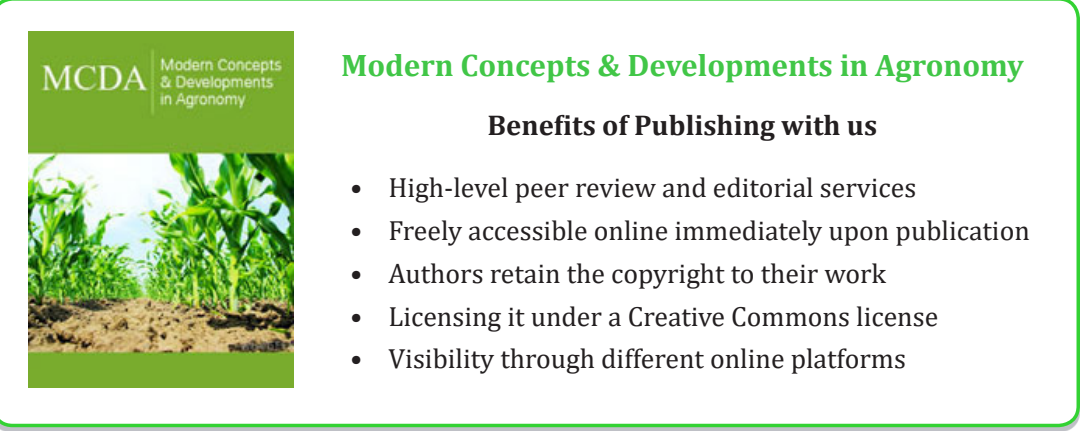

